DOI: 10.12731/2658-4034-2020-1-40-44

\title{
РОЛЬ СОВРЕМЕННЫХ ТЕХНОЛОГИЙ В РАЗВИТИИ КОММУНИКАТИВНОГО ОБУЧЕНИЯ ИНОСТРАННОМУ ЯЗЫКУ
}

\section{Кривочапкина А.Г.}

Северо-Восточный федеральный университет, г. Якутск,

Республика Саха (Якутия), Российская Федерация

В статье рассматривается использование различных современных технологий в качестве развития коммуникативных навыков студентов иностранному языку во время и вне учебного процесса.

Ключевые слова: коммуникативное обучение; коммуникативная деятельность; мобильные устройства; современные технологии; методь обучения; учебный процесс.

\section{THE ROLE OF MODERN TECHNOLOGIES IN DEVELOPMENT OF COMMUNICATIVE LANGUAGE TEACHING}

\section{Krivoshapkina A.G.}

North-Eastern Federal University, Yakutsk, Sakha Republic (Yakutia), Russian Federation

The article studies the use of various modern technologies as the development of students' communication language skills during and outside of the learning process.

Keywords: communicative language teaching; communicative activity; mobile device; modern technologies; teaching methods; learning process.

Коммуникативное обучение иностранному языку широко пропагандировалось как пригодное для всех контекстов, но с тех пор 
было поднято много вопросов о том, что оно на самом деле означает, какие его версии имеют отношение к конкретным учебным ситуациям. Обучение коммуникативному языку сегодня служит не столько ярлыком для конкретного подхода, сколько обобщающим термином для описания всех подходов, направленных на развитие коммуникативной компетентности.

Коммуникативная перспектива в языке предполагает, что когда мы изучаем иностранный язык, мы в первую очередь изучаем не языковые структуры, а языковые функции. Эти коммуникативные функции стали играть центральную роль в разработке и методологии учебных планов. В преподавание иностранного языка доминировали функциональные или коммуникативные курсы, в которых студенты практиковались в выражении таких функций, как построение предложений, а затем использовали их в коммуникативной деятельности, такой как парная работа, ролевая игра, обсуждение, использование аутентичных материалов. В то же время коммуникативная перспектива обучения фокусирует внимание на том, как мы учимся, и особенно на наших естественных языковых способностях просто через общение и без прямой помощи преподавателя. Эти две версии коммуникативного обучения языку имеют очень разные последствия для того, как язык лучше всего изучается в классе и для роли преподавателя. Обе версии требуют от преподавателя быть творцом и организатором коммуникативной деятельности. По этим причинам преподаватель может внедрять современные технологии в процесс обучения с целью повышения коммуникативных навыков. Например, мобильные устройства предлагают множество коммуникационных возможностей и могут быть использованы в качестве вспомогательного средства для общения. Skype можно использовать для поощрения студентов к общению с преподавателем и друг с другом. Сначала студенты задают друг другу вопросы с помощью преподавателя, но вскоре студенты становятся независимыми, и большая часть общения может происходить вне учебного процесса. Другой пример может показать, как студенты создают свои собственные учебные ресурсы из видеозаписей, которые они 
снимали, например, процесс приготовления блюда или создание электронной таблицы, а затем использовать их для описания процесса своему классу. Навыки проведения собеседований с учащимися можно практиковать, используя метод ролевых игр, во время которого сделать фотографии, затем применяя программное обеспечение, создать историю из фотографий. Многие возможности обучения могут быть запланированы с помощью мобильных устройств, способных делать фотографии событий, статей или этикеток, которые могут быть использованы в качестве подсказок для последующей письменной работы. Функция записи голоса на мобильных устройствах используется для записи, сравнения или описания некоторых событий, затем слушатели прослушивают запись голоса друг друга и оценивают произношение и использование различных грамматических структур. Ведение различных блогов является популярной формой записи мыслей и описание всевозможных событий. Этот тип коммуникационного моста мотивирует студентов к изучению иностранного языка. При использовании современных методов или мобильных телефонов для общения преподаватели отмечают, что динамика общения в классе повышается [1, с. 112]. Студенты чувствовали, что могут обращаться за помощью к другим студентам, а не зависеть от преподавателя. Многие студенты используют социальные сети, как часть своей повседневной жизни. Это использование вне учебного процесса, может способствовать развитию и поддержанию отношений и добавить к большей сплоченности и динамичности, когда они возвращаются в класс, который, в свою очередь, может оказать положительное влияние на их посещаемость и удержание на курсе. Современные технологии или цифровые инструменты позволяют студентам легко обмениваться своими работами и идеями с различными аудиториями, включая членов семьи и сверстников, членов местного сообщества и даже гораздо более широкий мир [2, с. 75]. Для некоторых процессов обучения интегрирующая технология помогает студентам достичь аутентичной аудитории, осознание того, что другие будут читать, смотреть, слушать и комментировать, может мотивировать студен- 
тов. Помимо связи студентов с реальной аудиторией, цифровые технологии предлагают практически неограниченные возможности для выхода из аудитории, студенты могут проконсультироваться с экспертами или преподавателями в ходе исследования конкретной темы. В этот момент мы можем разработать проект, чтобы студенты могли общаться с другими студентами из разных стран. Иногда такие способы обучения генерируют важную информацию или исследования, которые помогают сообществу решить проблему, и студенты становятся экспертами. Средства, предоставляемые мобильными устройствами, могут предложить высокоразвитый уровень независимости в использовании и помочь обеспечить связь с обществом в целом. Во многом это связано с тем, что пользователь может искать информацию в Интернете, например, планировщики путешествий и картографические приложения обеспечивают большую независимость для пользователя, позволяя ему самостоятельно находить информацию, доступ к которой часто осуществляется во время движения [3, с. 121].

Словарные, грамматические и орфографические приложения полезны, особенно там, где студенты могут также записывать свой собственный словарь в систему для последующего воспроизведения. Приложения переводчика идиом, были отмечены студентами как очень полезные. Энциклопедии полезны для поиска информации. Инструменты перевода текста, которые очень популярен среди студентов, полезны для перевода сложных или незнакомых слов и текстовых структур приложений. Информация, собранная с сайтов, которые описывают страны и культуры, путешествия, погода, информационные сайты новостей, покупки и оплата счетов с помощью онлайн, все это считается полезным [4, с. 168]. Все вышесказанное побуждает пользователя взаимодействовать с информацией на английском языке, читать и писать как формально, так и неофициально. Они побуждают пользователя чувствовать себя частью общества и устраняют потенциальные области стресса, например, необходимость, принимать участие в личном взаимодействии или совершать телефонные звонки для доступа к такой информации. 
За последние годы современные технологии развиваются очень быстро, произошел необычайный рост использования этих устройств до такой степени, что многие студенты, приходящие на занятия, теперь используют устройства высокой спецификации как часть своей жизни. Наряду с этим, можно также сделать вывод, что меняется роль и личность преподавателя. Преподаватели иностранного языка используют возможности обучения, которые присутствуют повсюду, чтобы помочь своим студентам улучшить свои навыки говорения и аудирования. Когда студенты приносят в класс мобильные устройства, преподаватели должны понимать, что их использование изменяет динамику процесса обучения, и они могут отказаться от контроля над классом и позволить студентам взять на себя ответственность за свое обучение в истинном смысле. Это дает студентам возможность взять на себя ответственность за создание собственных учебных ресурсов. Обучающихся можно поощрять к самостоятельной работе, а также к сотрудничеству друг с другом, и они начинают рассматривать обучение как нечто, что может быть интересным, осознавая ценность мобильных устройств в качестве инструмента обучения. Все технологии, доступные студентам, могут быть использованы в качестве устройств, которые обеспечивают связь для облегчения общения во время и вне учебного процесса. Необходимо, чтобы преподаватели шли в ногу с технологическим развитием и были осведомлены о навыках, способностях и общей грамотности учащихся, тем самым являясь отправной точкой преподавателя для совершенствования и дальнейшего развития языковых навыков своих студентов.

\section{Сиисок литературы / References}

1. Mallows D. Innovations in English language teaching for migrants and refugees. London: Brand and Design. 2012. 138 p.

2. Screvener J. Learning Teaching. MacMillan: London, 2010. 175 p.

3. Crabbe D. Learning opportunities: Adding learning value to tasks. ELT Journal. 2007. vol. 61 № 2, pp. 117-125 .

4. Pawling E. Modern languages and CD-ROM-based learning. British Journal of Technology. 1999. № 30(2), pp. 163-175. 